\title{
COLONIZATION PATTERNS OF VASCULAR PLANT SPECIES ON DECAYING LOGS OF FAGUS SYLVATICA L. IN A LOWER MOUNTAIN FOREST BELT: A CASE STUDY OF THE SUDETEN MOUNTAINS, (SOUTHERN POLAND)
}

\author{
STANIASZEK-KIK, M. ${ }^{1}$ - ŻARNOWIEC, J. ${ }^{2}$ - CHMURA, D. ${ }^{2 *}$ \\ ${ }^{1}$ Department of Geobotany and Plant Ecology, University of Łódź \\ ul. Banacha 12/16, 90-237 Łódź, Poland \\ (phone: (+48)42 6354401; fax: (+48)42 6354506) \\ ${ }^{2}$ Institute of Environmental Protection and Engineering, University of Bielsko-Biala \\ Willowa 2, 43-309 Bielsko-Biala, Poland \\ (phone: (+48) 33 8279185, fax. (+48) 033 8279101) \\ *Corresponding author \\ dchmura@ath.bielsko.pl, \\ (Received $5^{\text {th }}$ Sep 2013 ; accepted $22^{\text {nd }}$ July 2014)
}

\begin{abstract}
Little is known about the vascular plant flora that grows on dead wood or about the ecological conditions of its development. We focused on montane beech forests in the Sudeten Mts. in southern Poland and chose Fagus sylvatica. The studies were conducted in the years 2003-2006 between 460 and $890 \mathrm{~m}$ a.s.l. Among others, the following parameters of dead logs were recorded: the type of forest community, the status of protection (protected vs. managed), altitude, shade, the humidity of the log, the area of the $\log \left[\mathrm{m}^{2}\right]$ and the degree of the decomposition class. In total, 165 dead logs were analyzed. In total, 25 vascular plant species were encountered. Oxalis acetosella, Impatiens parviflora and Calamagrostis arundinacea were the most frequently found. The species composition of the colonized fallen logs differed significantly between the two forest communities in terms of DCA plot scores and also between the managed vs. protected forests. Canonical Constrained Analysis (CCA) revealed that decomposition degree, altitude and shade are significant factors among the five environmental variables that were studied. The study showed that the mean decomposition degree of beech logs as well as the cover of vascular plants overgrowing the logs was higher in the managed forests.
\end{abstract}

Keywords: coarse woody debris, fallen trees, beechwood, montane forests

\section{Introduction}

One of the features of natural and primeval forests is the amount of decaying dead wood. If dead wood is present in a semi-natural and managed forest, it can permit the maintenance of forest ecosystems that function properly. In Poland, the amount of dead wood is small, even in forest reserves (Pasierbek et al. 2007). Generally, in European montane regions, the percentage of dead wood is higher than in submontane regions and lowlands. On average, fallen dead wood contributes more to the total dead wood volume than standing dead wood, especially in beech forests (Christensen et al. 2005). Dead wood is important because it forms refuges for many living organisms, such as fungi, lichens, liverworts, mosses, invertebrates and vertebrates including amphibians, birds and small mammals (Ódor and van Hees 2004; Jonsson et al. 2005; Caruso et al. 2008; Ols et al. 2013). Vascular plants also inhabit dead wood; however, their habitats are mainly on the forest floor, i.e. mineral soils. Little is known about dead wood vascular plant flora and the ecological conditions of its development and its structure. 
Hopefully, this study will fill this gap to some extent. We focused on montane forests in the Karkonosze Mts. within Sudeten Mts range in southern Poland and chose one tree species - beech Fagus sylvatica. Due to intensive management and the exploitation of the temperate and boreal forests in Europe in the past, dead wood was relatively scarce or entirely absent over prolonged periods (Christensen et al. 2005). In the European beech forest zone, the degree of decomposition in available coarse dead wood is not known with certainty, but it is estimated to be comparable to the degree found in Fennoscandia which was estimated at 90-98\% (Christensen et al. 2005; Ódor et al. 2006). Generally, in the mountain region of Central Europe, human activity is weakened; therefore, remnants of semi-natural beech stands are more widespread and less disturbed than in the Atlantic lowlands of north-western Europe (Peterken 1996; Standovár and Kenderes 2003; Ódor et al. 2006). As a result, it can be expected that the flora that colonize the dead wood of Fagus sylvatica would be richer and more natural than in beechwoods located in lowlands.

The main goal was to examine whether dead wood serve as a important habitat for some vascular plants. The particular objectives of this study were to characterize the species composition of the vascular plant flora that colonize dead logs, to examine how the degree of decomposition, humidity and size of dead logs can impact the inhabiting plants as well as to check whether there are any differences between forest communities.

\section{Material and methods}

The studies were conducted in the years 2003-2006 in the area of the Karkonosze National Park (KNP) and its surroundings, in patches of the beech forests Dentario enneaphylli-Fagetum and Luzulo luzuloidis-Fagetum and a managed fir forest Picea abies between 460 and $890 \mathrm{~m}$ a.s.l. The Karkonosze Mt. range forms the border between Poland and the Czech Republic. It lies within the range of the Sudeten Mts. whose highest peak is Śnieżka (1602 m a.s.l.) This area is characterized by a severe high mountainous climate (Fig. 1). The montane vegetation is distributed along an altitude gradient: foothills (up to $500 \mathrm{~m}$ a.s.1.), lower forest montane zone (500-1000 m), upper forest montane zone $(1000-1250 \mathrm{~m})$, subalpine zone $(1250-1450 \mathrm{~m})$ and alpine zone (1450-1602 m). Because of human interference, profound changes have taken place. Anthropogenic Norway spruce tree stands have replaced the natural vegetation, which occur only fragmentarily nowadays. Norway spruce trees were introduced by foresters using seeds originating from the Alp Mts. Therefore, spruce mono-cultures were weakly resistant to both local biotic and abiotic conditions. Moreover, air pollution (sulphur dioxide, NOx and dusts, acid rains, etc.), which took place in the years 19601980, caused damage to the spruce leaves. As a consequence, the weakened trees of Picea abies were more vulnerable to fungi infections (Fabiszewski and Wojtuń1994; Stachurski et al. 1994). At present, spruce-cultures are in the decline in the Sudeten Mts. (Jadczyk 2009). For these reasons, forests in the Sudeten Mts. are rich in the dead wood of Picea abies. Because of the die-back of spruce, forest management practices are currently aimed at the reconstruction of tree stands. Therefore, beech Fagus sylvatica is being planted. In contradistinction to Norway spruce, the condition of beech trees is much better; however, it is less distributed than Norway spruce. Beech tree stands are mainly situated in the northern part of the KNP and in two enclaves of the KNP near Szklarska-Poręba and Jelenia Góra. Other trees stands of Fagus sylvatica are situated in 
the vicinity of the KNP near Kowary (Fig. 1). Almost all of the beechwoods were investigated in the study area. Amongst the various forms of dead wood, we chose selected forms of coarse dead wood, i.e. dead logs. Fine coarse dead wood and snags, stumps and tree fall disturbances were not taken into account in this study. All of the dead logs that were found were inventoried and analyzed in terms of selected biometric and habitat features. The following parameters of dead logs were recorded: GPS coordinates, the type of forest community, the status of protection (protected vs. managed), altitude, light availability (shading) in 5 degree scale ( 1 - full light, 5 - deep shade), the humidity of the log ( 1 - dry, 2 - intermediate, 3 - humid), the length of the $\log [\mathrm{m}]$, upper diameter $[\mathrm{cm}]$, lower diameter $[\mathrm{cm}]$, the area of the $\log \left[\mathrm{m}^{2}\right]$ and the class of decomposition (stage of decay). The area of the log was calculated using the formula for a truncated cone (Zielonka and Piątek 2004). The criterion of division into eight decomposition classes, which was originally used by McCullogh (1948) and with modifications by Dynesius and Johnsson (1991) and Holeksa (2001), was adapted after Zielonka and Piątek (2004). The percentage cover of vascular plants and the cover data of particular vascular plant species were noted. Moreover, total cover of moss species was recorded. The frequency of colonized dead logs vs. non-colonized dead logs in relation to the status protection of the forest was analyzed using the chi-squared test. The Spearman rank correlation test was used to examine the relationships between the analyzed variables. Because multiple tests were used, both the Holm adjusted p-values and in some cases p-values without correction were used following the recommendations by Moran (2003). The mean cover of vascular plant layer and the mean decomposition degree between the two phytocoenoses, Luzulo luzuloidis-Fagetum and Dentario enneaphylli-Fagetum, as well as between the managed and protected forests were compared using the Wilcoxon sum rank test. Detrended Correspondence Analysis (DCA) was used to study the variation of species turnover between the types of forest. The similarities of vegetation between the types of forest were compared by comparing the means of the coordinates of the plots along the two first axes of the DCA. The comparison of mean values permitted the identification of any significant differences in species composition between the groups of logs. The classification of indicator species for vegetation of groups of logs in particular forest communities was performed using the indicator value, i.e., the IndVal method (Cáceres et al. 2010). Constrained Correspondence Analysis (CCA) was used to analyze any differentiation of the species that colonize dead wood and the five selected environmental factors were used as the constrained variables. Strongly correlated variables with a high inflation factor were excluded from the analysis. The full model with 999 permutations of the Monte Carlo test was applied. All data analyses and calculations were done with R 2.15 software (R Core Team 2012).

\section{Results}

In total, 165 dead beech logs were analyzed including 128 in Luzulo luzuloidisFagetum, 27 in Dentario enneaphylli-Fagetum and 10 in the Picea abies community. When the presence/absence of plants encountered between the two former forest communities were compared, there was no significant difference (Fig. 2). Colonized dead logs in Luzulo luzuloidis-Fagetum and Dentario enneaphylli-Fagetum constituted $42.2 \%$ and $48.1 \%$, respectively. Of the total 25 vascular plant species, 14 vascular plant species were found in Dentario enneaphylli-Fagetum and 19 in Luzulo luzuloidis- 
Fagetum. The species composition of colonized fallen logs differs significantly between the two forest communities in terms of the mean values of the coordinates of the logs along the second DCA axis $(\mathrm{W}=170.5, \mathrm{p}<0.01)$ and between the managed vs. protected forests along both axes $(\mathrm{W}=249, \mathrm{p}<0.01, \mathrm{~W}=202, \mathrm{p}<0.01)($ Fig 3$)$.

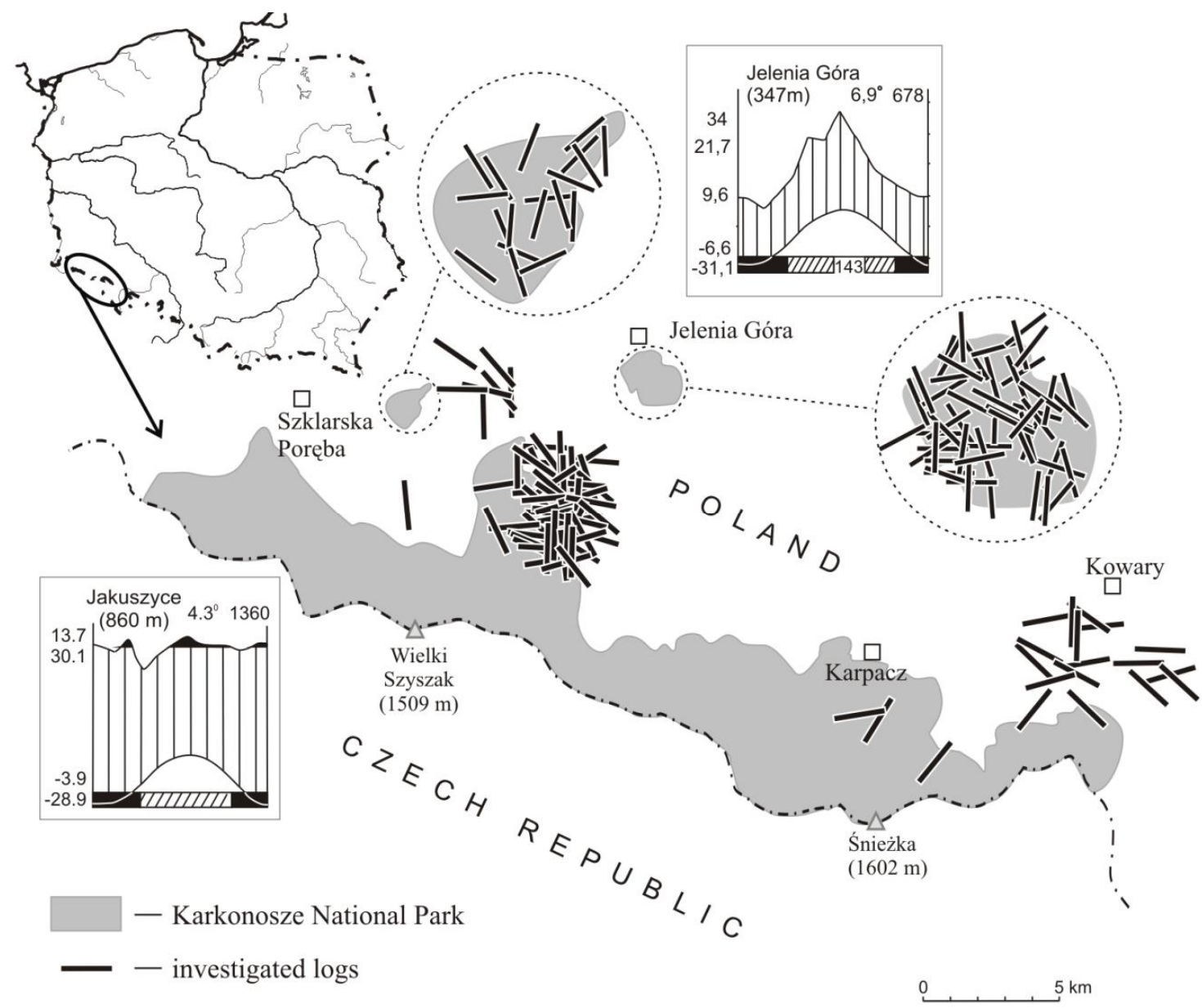

Figure 1. Distribution of the investigated logs of Fagus sylvatica and the climatic conditions of the study area.

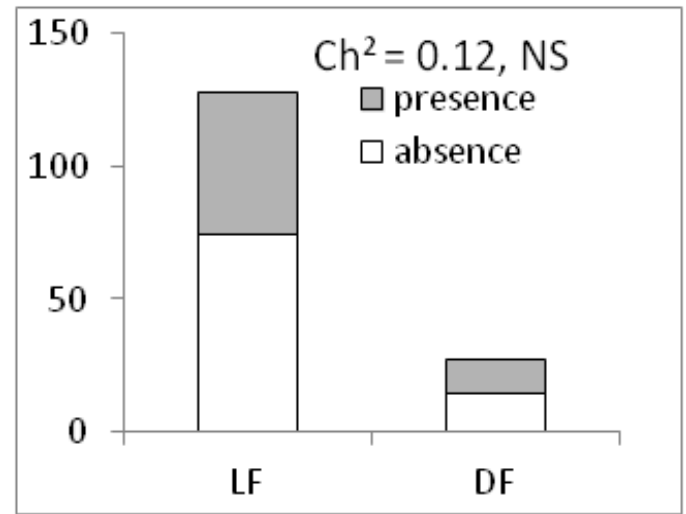

Figure 2. Comparison of the presencelabsence of plants on dead logs between the two types of forest community. LF - Luzulo luzuloidis-Fagetum, DF - Dentario enneaphylli-Fagetum. 

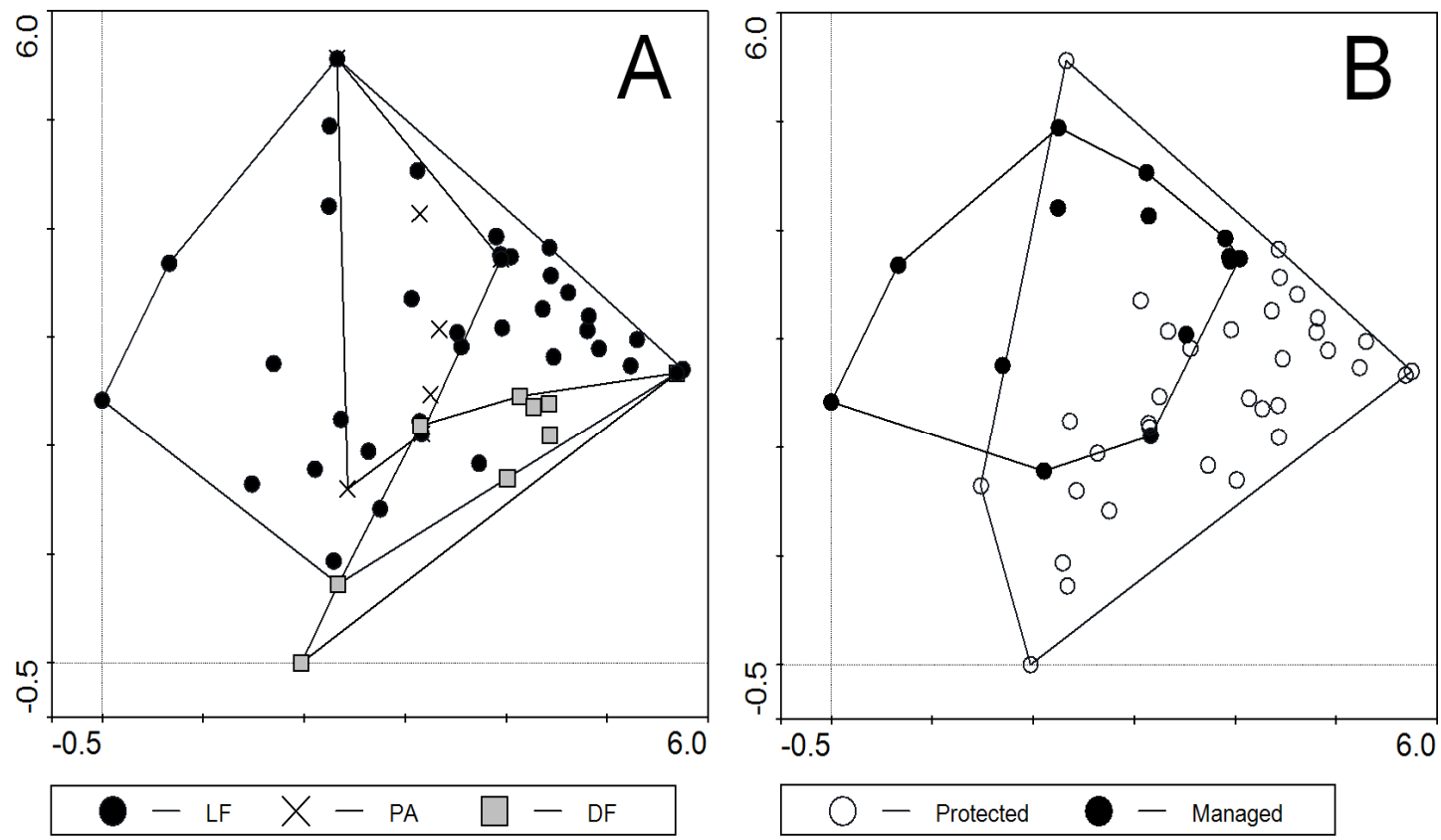

Figure 3. The ordination of the fallen logs of Fagus sylvatica along the two first DCA axes ( $\lambda 1$ $=0.803, \lambda 2=0.635$ ) based on the cover of colonizing vascular plant species in relation to the type of forest community and the protection status of the forests. LF - Luzulo luzuloidis-

Fagetum, DF - Dentario enneaphylli-Fagetum PA - Picea abies community.

Based on IndVal method two plants Picea abies (seedlings) and Dryopteris carthusiana are significantly indicator species for Luzulo luzuloidis-Fagetum scoring IndVal $=0.517, p=0.008$ and $0.411, p=0.028$ respectively. For two communities combined Dentario enneaphylli-Fagetum and Luzulo luzuloidis-Fagetum beech Fagus sylvatica as seedling is significant indicator (IndVal $=0.465, \mathrm{p}=0.043$ ).

Canonical Constrained Analysis (CCA) revealed that, among the environmental factors, the degree of decomposition, altitude and shade were significant factors accounting for $\mathrm{p}=0.001, \mathrm{p}=0.001$ and $\mathrm{p}=0.029$, respectively (Fig. 4). These three variables are arranged along the first axis of CCA. The most frequent species are Oxalis acetosella and Impatiens parviflora (Table 1). Species such as Vaccinium myrtillus, Convallaria majalis, Picea abies (seedlings), Urtica dioica and Luzula luzuloides are mainly associated with higher altitudes. Other species such as Fagus sylvatica (seedlings), Oxalis acetosella and Phegopteris connectilis are equally sensitive to the degree of decomposition, shading and altitude. Some species including Acer pseudoplatanus (seedlings), Dryopteris sp., Galeobdolon luteum or Poa nemoralis are confined to dead logs with a higher humidity; however, humidity was a non-significant factor in relation to species composition in general (Fig. 4).

The total cover of vascular plants was negatively correlated with altitude but positively with the degree of decomposition and humidity, as well as with the area of dead log coverage. Species richness was negatively correlated with altitude and positively correlated with the degree of the decomposition of dead logs. The number of species also increased significantly with an increasing area of dead log coverage. Vascular plants increase, in terms of their total cover and species richness, along with the increase of moss cover (Table 2). 


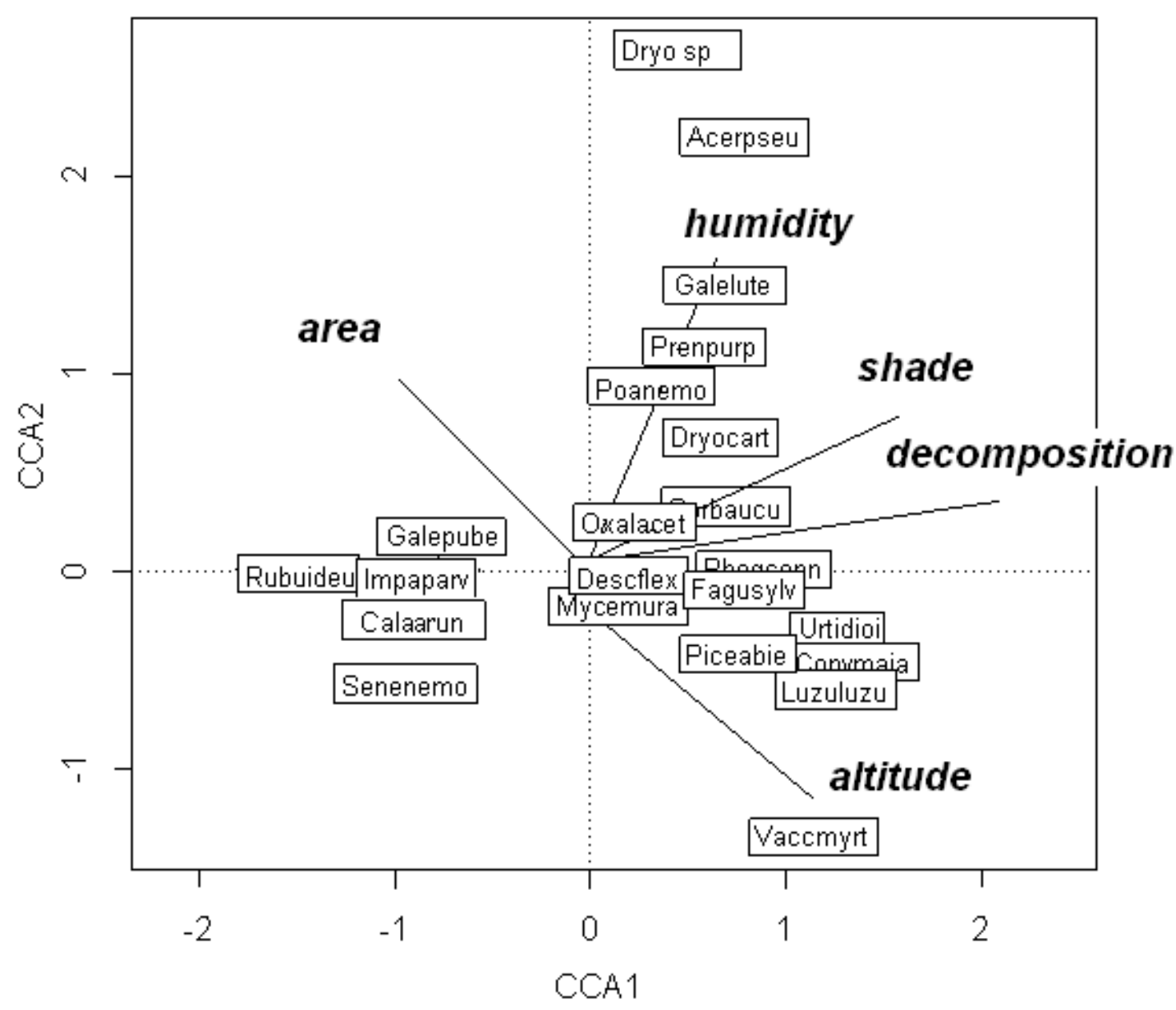

Figure 4. Biplot of plant species that colonize the dead logs of Fagus sylvatica along the two first axes of Constrained Correspondence Analysis $(C C A)(\lambda 1=0.58, \lambda 2=0.27)$. The diagram accounts for $10.6 \%$ and $66.8 \%$ of the variance of species cover data and species-environment relation, respectively. Only the degree of decomposition, altitude and shade are significant environmental factors. Abbreviations: Dryo sp-Dryopteris sp, Acerpseu-Acer pseudoplatanus, Calaarun-Calamagrostis arundinacea, Galelute - Galeobdolon lueum,

Prenpurp - Prenanthes purpurea, Poanemo - Poa nemoralis, Dryocart-Dryopteris carthusiana, Oxalacet - Oxalis acetosella, Galeopube - Galeopsis pubescens, RubuideuRubus idaeus, Impaparv - Impatiens parviflora, Descflex - Deschampsia flexuosa, Sorbaucu Sorbus aucuparia, Fagusylv - Fagus sylvatica, Urtidioi - Urtica dioica, Piceabie - Picea abies, Luzuluzu - Luzula luzuloides, Convmaja - Convallaria majalis, Senenemo - Senecio nemorensis, Vaccmyrt-Vaccinium myrtillus, Phegconn-Phegopteris connectilis.

The cover of vascular plants on decaying logs and the degree of decomposition did not differ significantly between the types of forest community. However, the status of protected forests did have an effect. In managed forests, independent of the type of community cover of plants, overgrown laying logs and the mean degree of decomposition were significantly higher (Fig. 5). 
Table 1. The number of occurrences of vascular plant species that colonize the fallen logs of Fagus sylvatica in Sudeten Mts

\begin{tabular}{lccc}
\hline Species & $\begin{array}{c}\text { Luzulo } \\
\text { luzuloidis- } \\
\text { Fagetum }\end{array}$ & $\begin{array}{c}\text { Dentario } \\
\text { enneaphylli- } \\
\text { Fagetum }\end{array}$ & $\begin{array}{c}\text { Picea abies } \\
\text { community }\end{array}$ \\
\hline Acer pseudoplatanus & 2 & 0 & 0 \\
Alliaria petiolata & 0 & 1 & 0 \\
Calamagrostis arundinacea & 12 & 1 & 0 \\
Convallaria majalis & 1 & 0 & 0 \\
Deschampsia flexuosa & 4 & 0 & 0 \\
Dryopteris carthusiana & 4 & 0 & 2 \\
Dryopteris sp. & 1 & 0 & 0 \\
Fagus sylvatica & 10 & 9 & 1 \\
Galeopsis pubescens & 1 & 0 & 0 \\
Hedera helix & 0 & 1 & 0 \\
Impatiens parviflora & 15 & 7 & 0 \\
Lamiastrum galeobdolon & 1 & 0 & 0 \\
Luzula luzuloides & 2 & 0 & 0 \\
Mercurialis perennis & 0 & 1 & 0 \\
Mycelis muralis & 0 & 1 & 4 \\
Oxalis acetosella & 30 & 3 & 0 \\
Phegopteris connectilis & 0 & 1 & 4 \\
Picea abies & 15 & 2 & 0 \\
Poa nemoralis & 0 & 1 & 0 \\
Polygonatum verticillatum & 1 & 0 & 0 \\
Prenanthes purpurea & 2 & 0 & 0 \\
Rubus ideus & 2 & 0 & 15 \\
Senecio nemorensis & 3 & 2 & 0 \\
Sorbus aucuparia & 1 & 1 & 0 \\
Urtica dioica & 0 & 32 & 0 \\
Vaccinium myrtillus & 113 & & 0 \\
Total & & 0 & 0 \\
\hline & 15 & 0 & 0 \\
\hline
\end{tabular}

Table 2. Intercorrelations (Spearman rank correlation) between the parameters associated with dead logs of Fagus sylvatica and the species that inhabit them

\begin{tabular}{|c|c|c|c|c|c|c|c|}
\hline & Altitude & $\begin{array}{l}\text { Mosses } \\
\text { cover }\end{array}$ & $\begin{array}{l}\text { Vascular } \\
\text { plants cover }\end{array}$ & $\begin{array}{l}\text { Decomposition } \\
\text { degree }\end{array}$ & Humidity & Shadow & Area \\
\hline Mosses cover & $-0.35^{4}$ & & & & & & \\
\hline $\begin{array}{l}\text { Vascular plants } \\
\text { cover }\end{array}$ & $-0.23^{2}$ & $0.51^{4}$ & & & & & \\
\hline $\begin{array}{l}\text { Decomposition } \\
\text { degree }\end{array}$ & ns & $0.41^{4}$ & $0.27^{4}$ & & & & \\
\hline Humidity & $\mathrm{ns}$ & $0.23^{3}$ & $0.19^{1}$ & $0.34^{4}$ & & & \\
\hline Shadow & ns & ns & ns & $0.29^{4}$ & $0.18^{1}$ & & \\
\hline Area of $\log$ & ns & ns & $0.21^{1}$ & $-0.32^{4}$ & ns & ns & \\
\hline $\begin{array}{l}\text { Species richness } \\
\text { of vascular plants }\end{array}$ & $-0.19^{1}$ & $0.48^{4}$ & $0.95^{4}$ & $0.25^{3}$ & ns & ns & 0.22 \\
\hline \multicolumn{8}{|c|}{ 1-p<0.05 without Holm's adjusted $p$-values, Holm's adjusted p-values: $2-p<0.05,3-p<0.01,4-p<0.001$} \\
\hline & $\begin{array}{l}\text { PPLIED EC } \\
\text { http://wwv }\end{array}$ & $\begin{array}{r}\text { aloki.hu } \bullet \text { I } \\
\text { DO } \\
\text { (C) } 2014\end{array}$ & $\begin{array}{l}\text { ENVIRONMEN } \\
\text { SN } 15891623(\mathrm{Pr} \\
: 10.15666 / \text { aeer/12 } \\
\text { ALOKI Kft., Bud }\end{array}$ & $\begin{array}{l}\text { TAL RESEARCH } 12(3 \\
\text { int) • ISSN } 17850037 \\
\text { 203_601613 } \\
\text { lapest, Hungary }\end{array}$ & $\begin{array}{l}\text { 3): 601-613. } \\
\text { (Online) }\end{array}$ & & \\
\hline
\end{tabular}



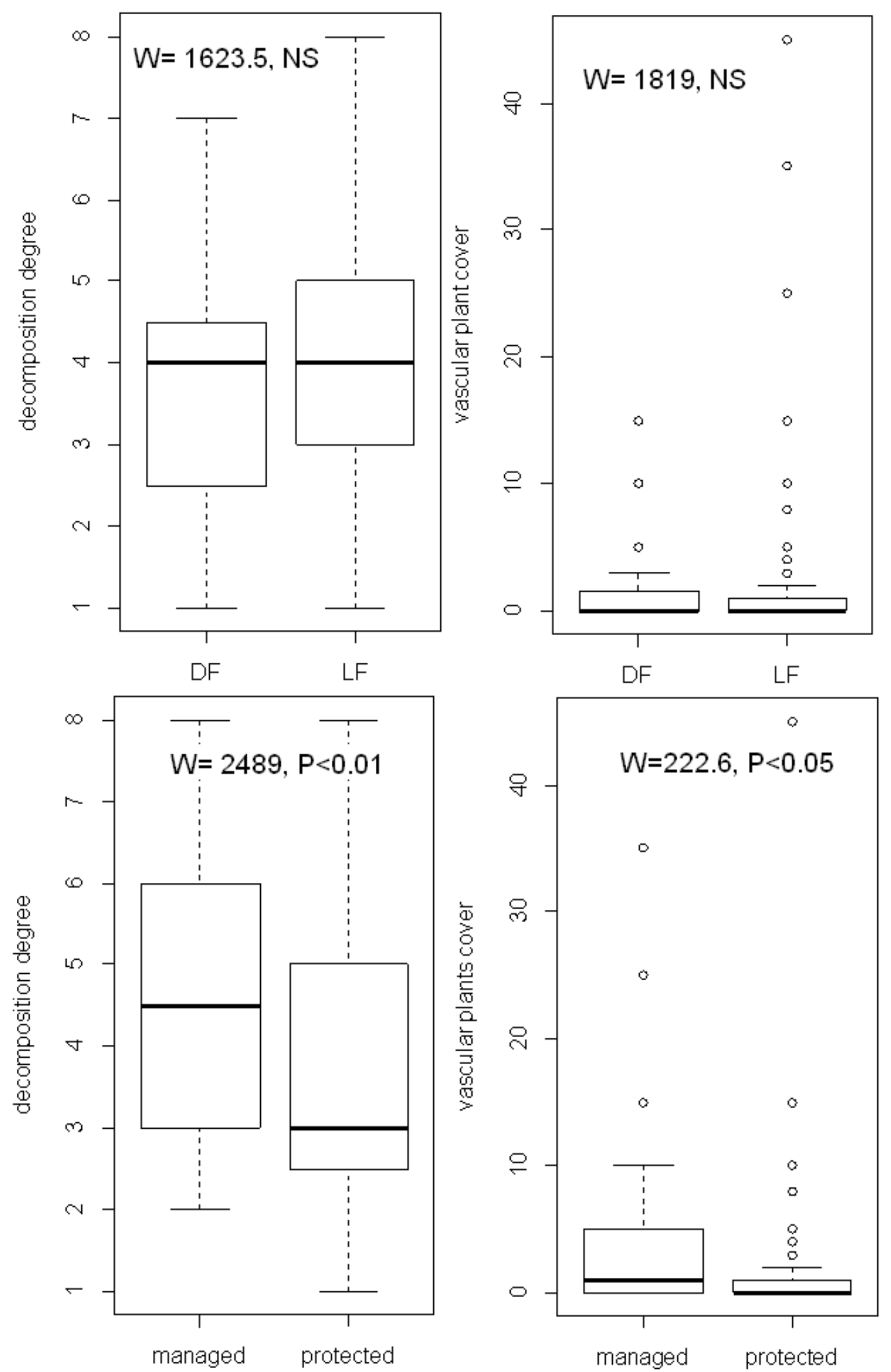

Figure 5. Comparison of the cover of vascular plant species and the degree of decomposition between the types of forest community LF Luzulo luzuloidis-Fagetum, DF Dentario enneaphylliFagetum and between managed and protected forests.

APPLIED ECOLOGY AND ENVIRONMENTAL RESEARCH 12(3): 601-613.

http://www.aloki.hu • ISSN 15891623 (Print) • ISSN 17850037 (Online)

DOI: $10.15666 /$ aeer/1203 601613

(C) 2014, ALÖKI Kft., Budapest, Hungary 


\section{Discussion}

Vascular plant species in contradistinction to epixylic species such as lichens, mosses and liverworts are "true" colonizers of dead wood. These plants colonize dead wood from substrate as bare soil or litter in the course of dead wood decomposition. They are usually not encountered on living trees in temperate regions, whereas cryptogamous plants and mosses can be found on the bark of living trees very frequently. Thus, lichens and bryophytes growing on dead wood are most frequently relics of epiphytic flora, but only in some stages of decay. In the literature, there is almost no information about the species richness and species composition of vascular plant taxa that inhabit the dead wood of Fagus sylvatica.

The exception is a study by Chmura (2008), who found 12 vascular plant species on 29 decaying logs in a much smaller area in one nature reserve in lowlands in the Dentario glandulosae-Fagetum community. However, such data is available for cryptogams. Żarnowiec and Staniaszek-Kik (2009) found 19 lichens, 3 liverworts and 19 mosses on dead logs of beech in a Dentario enneaphylli-Fagetum community in the same region. The number of species of vascular plant flora in this study was slightly lower -14 . Other deciduous trees whose fallen logs were studied in terms of the species composition of colonizing flora had a similar species richness of the 26 vascular plant species found on the logs of all of the tree species studied including pine Pinus sylvestris: birch Betula pendula and aspen Populus tremula (16), hornbeam Carpinus betulus (12) and oaks Quercus sp. (22) (Nowińska et al. 2009).

On decaying logs of the spruce Picea abies in a subalpine forest PlagiothecioPiceetum in the Tatra Mountains, the species richness of vascular plants was higher when compared to this study (20); however, a larger number of logs were observed (Zielonka and Piątek 2004). Similar species richness (23) on spruce logs was found by Kushnevskaya et al. (2007) in the late-successional boreal forests of north-western Russia. In contrast, in the Primeval Bialowieża Forest, 108 species were observed on the wood and 138 on the bark of the laying logs of 303 vascular plant species that were reported from six forest communities growing on different substrates (Chlebicki et al. 1996). Zielonka and Piątek (2004), Chmura (2008) and Nowińska et al. (2009) demonstrated that, with a more advanced decomposition stage, the number of species increases; this was confirmed by our observations. In addition, a positive relationship was also found for the total cover of all plants (Table 2).

The previous authors claim that the $6^{\text {th }}$ stage has the most suitable conditions for vascular plants. With an increasing coverage area of logs, the number and cover of vascular plant species increases; however, this is a weak correlation (Table 2). It is interesting that such a positive relationship was found for the coverage area of log and the degree of decomposition. In the first case, it is a well-known phenomenon called the species-area relationship (Rosenzweig 1995), which is also true for small objects in the microscale.

The total number of individuals increases with area, leading to an increased probability of encountering more species within larger areas (Scheiner et al. 2000). Moreover, the larger logs are likely to be more heterogeneous as to types of microsites. Those which can be found on logs are: bark, wood at different decomposition stages, moss mats, cracks in stems filled with mineral soil or humus (Nowińska et al. 2009). The pattern that was observed is in contrast to the colonization of Picea abies logs in the Tatra Mts, where thick logs had a lower cover of herbs than thin logs. Medium logs were mostly covered by herbaceous plants (Zielonka and Piątek 2004). The second case 
is more intriguing. Perhaps it is a coincidence or it may be connected with the age of the trees and the time that had passed since their fall which enabled colonization.

We found that the degree of decomposition increases when light availability is lower. This may be associated with other findings, i.e. a positive correlation between shade and humidity. Moisture enhances the process of decomposition, but light can lead to an increase in temperature and the drying out of the bark and wood of decaying logs. Generally, moisture is believed to increase significantly during wood decay (Bütler et al. 2007). Vascular plants responded similarly as mosses what was manifested by positive correlation (Table 2). Mosses are known to keep humidity what explain why vascular plant are associated with them on decaying logs.

In this study, both species richness and the cover of vascular plants decreased with increasing altitude. Two species were found to be frequent colonizers: Oxalis acetosella and Impatiens parviflora. The former is a native plant with a rather wide synecological amplitude. In contradistinction to the latter, it seems to be more confined to the dead wood of Pinus sylvestris (Nowińska et al. 2009) than to deciduous trees. Furthermore, as the study by Zielonka and Piątek (2004) showed, this species had a positive response to the degree of decomposition of Pinus sylvestris logs. In the case of beech, the species was frequent enough that no environmental factors influenced its behavior (Fig. 4). Its common or even massive presence in the Sudeten Mts. is caused by the encroachment of many lowland species into afforested areas due to the decline of Norway spruce stands. Oxalis acetosella was one of the few species that did not disappear because of spruce regeneration. Its further spread into other types of woods was possible owing to its wide ecological tolerance (Jadczyk 2009). Small balsam Impatiens parviflora is one of the most invasive alien neophytes in Polish and European flora (Tokarska-Guzik 2005; Hejda 2012) and has successfully penetrated natural forest communities including nature reserves (Chmura and Gucwa-Przepióra 2012; Schmidt 2012). Previously, it was reported as the most common colonizing species on beech dead wood (Chmura 2008) and hornbeam Carpinus betulus, pine Pinus sylvestris (Piskorz and Klimko 2001) and oaks (Quercus sp)(Nowińska et al. 2009). Amongst the almost 1,600 various structural elements of dead wood (logs, snags, stumps, tree-fall disturbances) of Fagus sylvatica and Picea abies in the Sudeten Mts., Staniaszek-Kik and Żarnowiec (2012) found the species on 44 elements, mainly on the logs and stumps of Fagus sylvatica. The present detailed study demonstrated that Impatiens parviflora does not show any species preferences for significant environmental factors, such as shading, altitude and the degree of decomposition. Vaccinium myrtillus or Luzula luzuloides are associated with a higher altitude, especially the former, and occur more frequently in subalpine spruce forests. Analyzing most frequent, indicator species for particular plant communities where decaying logs were studied it can be inferred that there are no exclusively vascular plants inhabiting dead wood. All of them are common forest floor species both herbaceous and seedlings of trees. One of them, indicated in the study, is Picea abies which commonly is reported to regenerate on dead wood (Holeksa 2001) or Fagus sylvatica which obviously is common in beechwoods. In disturbed forest i.e. Picea abies community no significant indicator plant species were noted. The data that showed a higher mean decomposition stage and a higher mean cover of vascular plants on logs in managed forests than protected ones could be a result of forest management practices and the disturbances that are associated with them. The quantities of dead wood are normally much lower in managed forests than in unmanaged old-growth forests (Ódor and Standovar 2001). However, forest management treatments can lead to 
a more abundant presence of dead wood because of artificial tree stand thinning and the abandonment of logs. As a consequence, according to the intermediate disturbance hypothesis, species richness and species diversity is higher (Wilkison 1999). The results suggest that a greater number of disturbances favors the development of vascular plants on decaying logs (Fig. 3). Unknown role of plants in acceleration of decomposition of dead wood due to mechanical action of roots should be further studied in the future. Perhaps vascular plants enhances to nutrient cycling of dead wood in forest ecosystems.

To sum up, it can be concluded that the species diversity of vascular flora that colonize the logs of Fagus sylvatica does not differ significantly on floras inhabiting the dead wood of other deciduous trees and even conifers. It is rather species-poor, with a single common species. Contrary to epiphytic and epixylic mosses and lichens vascular plants present on decaying logs are common species, thus dead wood does not contribute to species richness and diversity of this group of taxa.

Acknowledgements. Authors thank Michelle Simmons for improving language of the manuscript.

\section{REFERENCES}

[1] Bütler R, Patty L, Le Bayon RC, Guenat C., Schlaepfer R (2007): Log decay of Picea abies in the Swiss Jura Mountains of central Europe. - Forest Ecol Manag 242 791-799. doi:10.1016/j.foreco.2007.02.017

[2] Cáceres M.D, Legendre P., Moretti M. 2010. Improving indicator species analysis by combining groups of sites. Oikos: 119(10): 1674-1684.

[3] Caruso A, Rudolphi J, Thor G (2008): Lichen species diversity and substrate amounts in young planted boreal forests: A comparison between slash and stumps of Picea abies. Biol Conserv 141 (1): 47-55. doi:10.1016/j.biocon.2007.08.021

[4] Chlebicki A, Żarnowiec J, Cieśliński S, Klama H, Bujakiewicz A, Załuski T (1996): Epixylites, lignicolous fungi and their links with different kinds of wood. In Faliński J.B., Mułenko W. (eds) Cryptogamous plants in the forest communities of Białowieża National Park (Project CRYPTO). Phytocoenosis 8. N.S. Archiv. Geobot. 6: 75-110.

[5] Chmura D (2008): The colonization of coarse woody debris of Fagus sylvatica by forest herbs in Bukowica reserve (S Poland). - Rocz. AR Pozn. 387, Bot.-Stec. 12: 3-7.

[6] Chmura D (2008): Slope aspect affects homogeneity and growth of ground vegetation in deciduous forest. - Pol J Ecol 56(3): 463-470.

[7] Chmura D, Gucwa-Przepiora E (2012): Interactions between arbuscular mycorrhiza and the growth of the invasive alien annual Impatiens parviflora DC: A study of forest type and soil properties in nature reserves (S Poland). - Appl Soil Ecol 62: 71-80. doi: 10.1016/j.apsoil.2012.07.013

[8] Christensen M, Hahn K, Mountford EP, Ódor P, Standovar T, Rozenbergar D, Diaci J, Wijdeven S, Meyer P, Winter S, Vrska T (2005): Dead wood in European beech (Fagus sylvatica) forest reserves. - Forest Ecol Manag 210 (1-3): 267-282. doi:10.1016/j.foreco.2005.02.032

[9] Dynesius M, Johnsson BG (1991): Dating uprooted trees: comparison and application of eight methods in a boreal forest. - Can J Forest Res 21: 655-665

[10] Fabiszewski J, Wojtuń B (1994): Die begleitenden ökologischen Erscheinungen des Waldsterbenprozesses im Sudetengebrige]. Prace Instytutu Badań Leśnych B, 21: 195210. (in Polish with German summary).

[11] Hejda M (2012): What is the impact of Impatiens parviflora on diversity and composition of herbal layer communities of temperate forests? - PLoS ONE 7 (6), e39571. doi:10.1371/Fjournal.pone.0039571

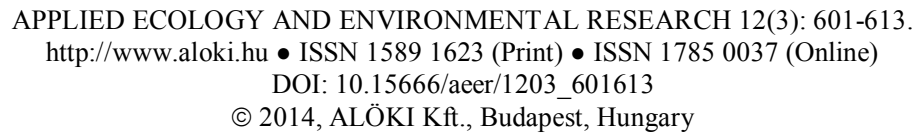


[12] Holeksa J (2001): Coarse woody debris in a Carpathian subalpine spruce forest. Forstwiss Centralbl 120: 256-270

[13] Jadczyk P (2009): Natural effects of large-area forest decline in the Western Sudeten. Environ Prot Eng 35(1): 49-56.

[14] Jonsson BG, Kruys N, Ranius T (2005): Ecology of species on dead wood - lessons for dead wood management. - Silva Fenn 39(2): 289-309.

[15] Kushnevskaya H, Mirin D, Shorohova E (2007): Patterns of epixylic vegetation on spruce $\operatorname{logs}$ in late-successional boreal forests. - Forest Ecol Manag 250: 25-33. doi:10.1016/j.foreco.2007.03.006

[16] McCullough HA (1948): Plant Succession on Fallen Logs in a Virgin Spruce-Fir Forest. Ecology 29(4): 508-513.

[17] Moran MD (2003): Arguments for rejecting the sequential Bonferroni in ecological studies. - Oikos 100(2): 403-405. DOI: 10.1034/j.1600-0706.2003.12010.x

[18] Nowińska R., Urbański P., Szewczyk W. (2009): Species diversity of plants and fungi on logs of fallen trees of different species in oak-hornbeam forests. - Roczniki Akademii Rolniczej Pozn. 388, Botanika-Steciana. 13: 109-124.

[19] Ódor P, Heilmann-Clausen J, Christensen M, Aude E, van Dort KW, Piltaver A, Siller I. Veerkamp MT, Walleyn R, Standovar T, van Hees AFM, Kosec J, Matocec N, Kraigher $\mathrm{H}$, Grebenc T (2006): Diversity of dead wood inhabiting fungi and bryophytes in seminatural beech forests in Europe. - Biol Conserv 131 (1): 58-71. doi:10.1016/j.biocon.2006.02.004

[20] Ódor P, van Hees Ad FM (2004): Preferences of dead wood inhabiting bryophytes for decay stage, log size and habitat types in Hungarian beech forests. - J Bryol 26: 79-95. doi: $0.1179 / 037366804225021038$

[21] Ódor P, Standovár T, (2001): Richness of bryophyte vegetation in a near-natural and managed beech stands: the effects of management-induced differences in dead wood. Ecol Bull 49: 219-229.

[22] Ols C., Victorsson J., Jonsell M. (2013): Saproxylic insect fauna in stumps on wet and dry soil: Implications for stump harvest. - Forest Ecol Manag 290: 15-21. doi: 10.1016/j.foreco.2012.08.040

[23] Pasierbek T, Holeksa J, Wilczek Z, Żywiec M (2007): Why the amount of dead wood in Polish forest reserves is so small? - Nat Conserv 64(7): 65-71.

[24] Peterken GF (1996): Natural Woodland. Ecology and Conservation in Northern Temperate Regions. Cambridge University Press, Cambridge.

[25] Piskorz R, Klimko M (2001): Colonization of fallen trees and rooted ground by Impatiens parviflora DC. in communities of Galio silvatici-Carpinetum in selected forest reserves in the Wielkopolska National Park]. - Rocz AR Pozn. 334, Bot-Stec 4: 151-162. (in Polish with English summary).

[26] R Core Team (2012): R: A language and environment for statistical computing. $\mathrm{R}$ Foundation for Statistical Computing, Vienna, Austria. ISBN 3-900051-07-0, URL http://www.R-project.org/.

[27] Rosenzweig ML (1995): Species Diversity in Space and Time. Cambridge University Press, Cambridge.

[28] Scheiner SM, Cox SBH, Willig M, Mittelbach GG, Osenberg C, Kaspari M (2000): Species richness, species-area curves and Simpson's paradox. - Evol Ecol Res 2: 791802.

[29] Schmidt W (2012): How natural are strict forest reserves? Neophytes and therophytes as geobotanical indicators. - Forstarchiv 83: 93-108.

[30] Stachurski A, Zimka JR, Kwiecien M (1994): Forest decline in Karkonosze Poland. I. Chlorophyll, phenols, defoliation index and nutrient status of the Norway spruce (Picea abies L.) - Ekol Polska 42, (3-4): 286-316.

[31] Standovár T, Kenderes K (2003): A review on natural stand dynamics in beech woods of East Central Europe. - Appl Ecol Environ Res 1: 19-46. 
[32] Staniaszek-Kik M, Żarnowiec J (2013): Invasive alien plants on decaying wood and on tree-fall disturbances in forests in the Karkonosze Mts (Sudeten, Sw Poland). I- nżynieria Ekologiczna 32: 155-163. (in Polish with English summary).

[33] Tokarska-Guzik B (2005): The establishment and spread of alien plant species (kenophytes) in the flora of Poland. Uniwersytet Śląski, Katowice. pp. 192.

[34] Wilkison DM (1999): The disturbing history of intermediate disturbance. Oikos 84(1): $145-147$.

[35] Żarnowiec J, Staniaszek-Kik M (2009): Distribution patterns of bryophyte and lichen species richness and diversity in Dentario enneaphylli-Fagetum in the Chojnik Mt (Karkonosze National Park, SW Poland). - Ochrona Środowiska i Zasobów Naturalnych 38: 409-418.

[36] Zielonka T, Piątek G (2004): The herb layer and dwarf shrubs colonization of decaying logs in subalpine forest in the Polish Tatra Mountains. - Plant Ecol 172: 63-72. 